\title{
Molecular Diversity in Bulgarian and Cypriot Barley Germplasm Collections - A Reference Point for Better Understanding, Exploitation and Improvement of Adaptiveness to Agro-Climatic Conditions
}

\author{
EG Todorovska*1, D Fasoula ${ }^{2}$ and I Ioannides ${ }^{2}$ \\ ${ }^{1}$ Agro Bio Institute, Bulgaria \\ ${ }^{2}$ Agricultural Research Institute, Cyprus
}

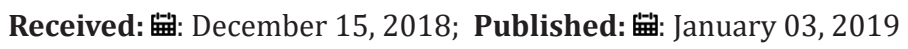

*Corresponding author: Elena G Todorovska, Agro Bio Institute, Bulgaria

\section{Introduction}

Barley is one of the major crops for Bulgaria and Cyprus. Knowledge of genetic diversity in barley germplasm helps to ensure that a broad genetic base of breeding materials is maintained not just for sustaining genetic improvement but also for reducing genetic vulnerability to pest, biotic and abiotic stresses. The changeable climatic conditions require precise selection of new cultivars and advanced breeding lines for high yield, tolerance to multiple stress factors and adaptation to different agro-climatic conditions. Responding to the demands for improvement of cereal crops in Bulgaria and Cyprus, a large scale characterization of native and newly introduced valuable germplasm was initiated by molecular markers. The objective of the present study is to compare and explore the genetic diversity in Bulgarian and Cypriot barley collections by SSR markers.

\section{Materials and Methods}

\section{Plant Material}

60 accessions of winter and spring two- and six- row barley representing the present-day germplasm from the collections of Agricultural Institute, Karnobat, Bulgaria and Agricultural Research Institute, Nicosia, Cyprus were selected for molecular analysis.

\section{Microsatellite Markers and Fragment Analyses}

Twelve genomic- and five EST-SSRs [1] were used in the study. Fragment analysis of all SSRs was carried out on ALF ExpressII sequencer and fragment sizes were determined using the computer program Allele Locator v. 1.03 (Amersham Biosciences).

\section{Data Analysis}

The genetic similarities for each pairs of lines were calculated from a binary matrix using the Dice similarity index. Cluster analyses were performed by UPGMA method with NTSYS-pc ver. 2.11 package. Gene diversity (GD) was calculated using the formula of [2].

\section{Results and Discussion}

Sixty accessions covering a wide spectrum of genetic diversity of cultivated barley gene pool from different agro-geographical areas (Bulgaria, Central Europe and Cyprus) were characterized at 17 SSR loci. In total, 107 alleles with an average 6.29 alleles/locus were identified with an average $\mathrm{GD}=0.591$. Comparative analysis of gene diversity among germplasm pools from both geographical regions (Table 1) showed higher GD in Cypriot barley in comparison to European barley (0.542 vs. 0.506). Site-of-origin eco-geographic variation of the level of genetic diversity in barley germplasm was observed. European and Cypriot accessions possessing rare alleles at many different loci were detected and could be effectively used for broadening the allelic diversity and the potential for cultivar improvement of barley. The study also clearly showed that the functional diversity revealed by EST-SSRs is higher in Cypriot germplasm collection $(\mathrm{GD}=0.484)$ which confirms the role of the variation in the studied transcribed gene regions in adaptiveness to different climatic conditions (Table 2). The constructed dendrograms showed specific grouping of European and Cypriot germplasm pools in two well distinguished clusters (Figure 1). 
The present study is a base for further analysis of the genomics regions involved in adaptiveness of barley to different agro-climatic conditions and improvement of breeding programmers in Bulgaria and Cyprus by reducing the vulnerability of climate changes and ensuring food security.

Table 1: Description of 17 microsatellite loci, number of alleles and genetic diversity (GD) across 60 Bulgarian, European and Cypriot barley.

\begin{tabular}{|c|c|c|c|c|c|c|}
\hline \multirow{2}{*}{$\begin{array}{l}\text { SSR Markers and } \\
\text { Chromosome } \\
\text { Location }\end{array}$} & \multicolumn{2}{|c|}{$\begin{array}{c}\text { Bulgarian, European and Cypriot } \\
\text { Germplasm }\end{array}$} & \multicolumn{2}{|c|}{ Bulgarian and European Germplasm } & \multicolumn{2}{|c|}{ Cypriot Germplasm } \\
\hline & No of Alleles & Genetic Diversity & No of Alleles & Genetic Diversity & No of Alleles & Genetic Diversity \\
\hline HVM03-4L & 15 & 0.888 & 15 & 0.878 & 7 & 0.648 \\
\hline HVM04-1S & 11 & 0.802 & 7 & 0.726 & 7 & 0.750 \\
\hline HVM27-3S & 4 & 0.690 & 3 & 0.592 & 3 & 0.477 \\
\hline HVM30-7S & 1 & 0.00 & 1 & 0.00 & 1 & 0.00 \\
\hline HVM36-2S & 7 & 0.807 & 5 & 0.749 & 4 & 0.711 \\
\hline HVM40-4S & 4 & 0.538 & 3 & 0.308 & 3 & 0.406 \\
\hline HVM43-5L & 4 & 0.579 & 4 & 0.440 & 2 & 0.375 \\
\hline HVM 49-1L & 8 & 0.674 & 6 & 0.531 & 5 & 0.750 \\
\hline HVM 60-3L & 7 & 0.793 & 6 & 0.736 & 3 & 0.477 \\
\hline HVM 62-3L & 11 & 0.829 & 9 & 0.767 & 5 & 0.727 \\
\hline HVM 674L & 5 & 0.585 & 3 & 0.495 & 5 & 0.703 \\
\hline HVM 74-6S & 11 & 0.816 & 9 & 0.787 & 5 & 0.769 \\
\hline GBM1022-6L & 5 & 0.747 & 5 & 0.714 & 4 & 0.648 \\
\hline GBM1042-5S & 2 & 0.299 & 2 & 0.325 & 2 & 0.219 \\
\hline GBM1045-7L & 4 & 0.242 & 3 & 0.168 & 2 & 0.375 \\
\hline GBM1047-2L & 5 & 0.520 & 3 & 0.346 & 5 & 0.609 \\
\hline GBM1060-1S & 3 & 0.238 & 2 & 0.044 & 3 & 0.570 \\
\hline MEAN & 6.294 & 0.591 & 5.059 & 0.506 & 3.882 & 0.542 \\
\hline Total & 107 & & 86 & & 66 & \\
\hline
\end{tabular}

Table 2: Comparison of the genetic diversity in germplasm pools from different agro-geographical regions estimated by genomic and EST-SSRs.

\begin{tabular}{|c|c|c|}
\hline \multirow{2}{*}{ Germplasm } & \multicolumn{2}{|c|}{ Genetic Diversity (GD) } \\
\cline { 2 - 4 } & Genomic SSRs & 0.409 \\
\hline Bulgarian, European and Cypriot & 0.667 & 0.32 \\
\hline Bulgarian and European & 0.584 & 0.484 \\
\hline Cypriot & 0.566 & \\
\hline
\end{tabular}

Cite this article: EG Todorovska, D Fasoula,I Ioannides. Molecular Diversity in Bulgarian and Cypriot Barley Germplasm Collections - A Reference Point for Better Understanding, Exploitation and Improvement of Adaptiveness to Agro-Climatic Conditions. Biomed J Sci \& Tech Res 


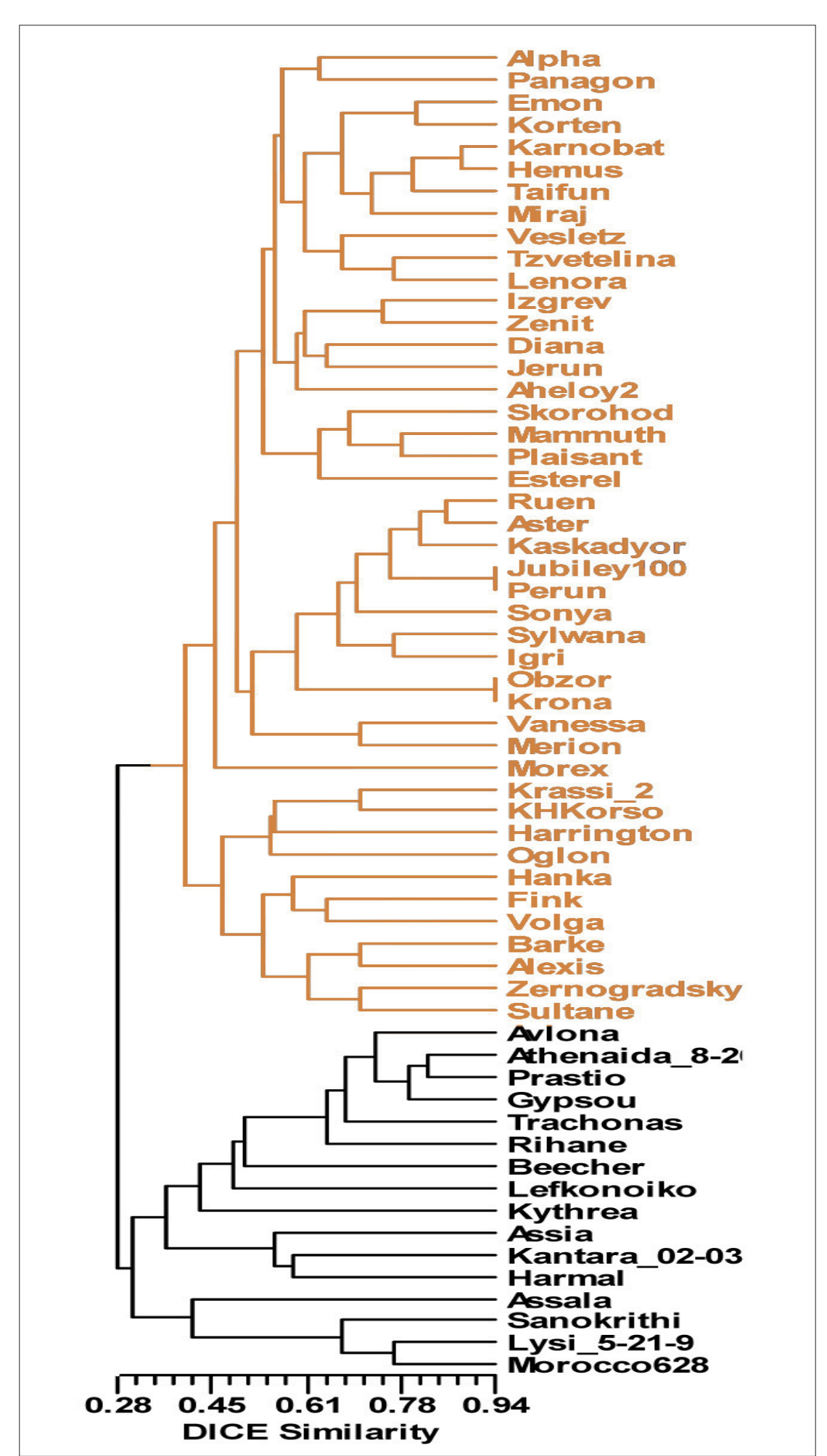

Figure 1: Dendrogramme of 60 barley accessions genotyped at 17 SSR loci.

\section{References}

1. Thiel T, Michalek W, Varshney R, Graner A (2003) Exploiting EST databases for the development and characterization of gene-derived SSR-markers in barley (Hordeum vulgare L.). Theor Appl Genet 106(3): 411-422.
2. Nei M (1973) Analysis of gene diversity in subdivided populations. Proc Natl Acad Sci USA 70(12): 3321-3323. 
ISSN: 2574-1241

DOI: $10.26717 / B J S T R .2019 .12 .002300$

Elena G Todorovska. Biomed J Sci \& Tech Res

(c) (P) This work is licensed under Creative

Submission Link: https://biomedres.us/submit-manuscript.php

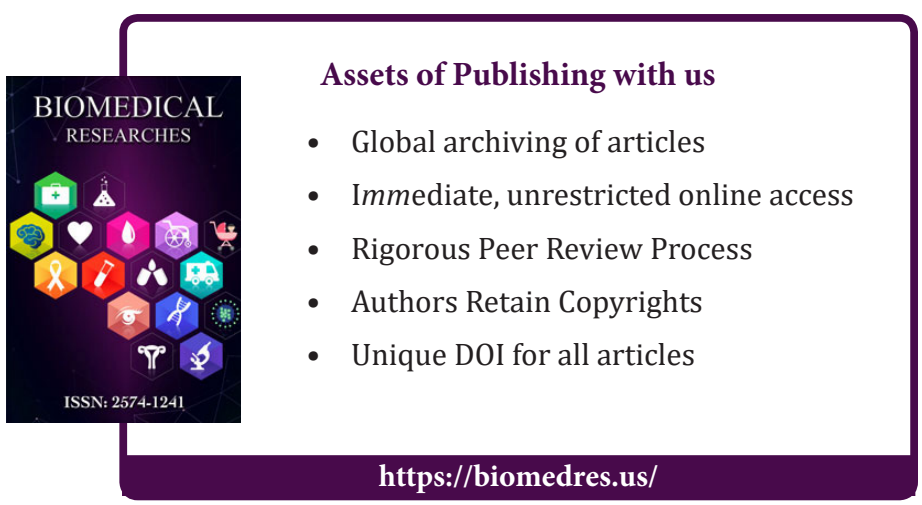

